\title{
Pengaruh Kampanye Cup of Courage Starbucks terhadap Minat Beli Produk Minuman Pink Voice di Starbucks Stasiun Jakarta Kota
}

\author{
Reynaldi Putra, Diah Ayu Candraningrum \\ reyputra218@gmail.com,diahc@fikom.untar.ac.id \\ Fakultas Ilmu Komunikasi Universitas Tarumanagara
}

\begin{abstract}
Along with the habits of the Indonesian people in consuming coffee which has become a hereditary tradition, many coffee shops with new brands and identities are starting to emerge and spread in various regions in Indonesia. One of the biggest companies in the world in the coffee industry is Starbucks. This study discusses one of the Starbucks campaigns that carries the theme of Cup of Courage. In this study there are two variables, namely the campaign variable and buying interest. This study uses quantitative techniques with survey methods and uses Starbucks Jakarta City Station as an observation unit. Primary data were collected by purposive sampling method, and 100 respondents were collected who were directly related to the Cup of Courage campaign. Data analysis using SPSS for windows 15. Based on the results of research conducted there is a very strong influence between the Cup of Courage campaign on buying interest in Pink Voice beverage products, which are in the interval 0.8-1.00 on the correlation coefficient test results.
\end{abstract}

Keywords: aida, buying interest, campaign

\begin{abstract}
Abstrak
Seiring dengan kebiasaan masyarakat Indonesia dalam mengkonsumsi kopi yang sudah menjadi tradisi turun temurun, banyak kedai kopi dengan merek dan identitas baru yang mulai bermunculan dan tersebar di berbagai daerah di Indonesia. Salah satu perusahaan besar di dunia dalam bidang industri kopi ialah Starbucks. Penelitian ini membahas mengenai salah satu kampanye Starbucks yang mengusung tema Cup Of Courage. Didalam penelitian ini terdapat dua variabel, yaitu variabel kampanye dan minat beli. Penelitian ini menggunakan pendekatan penelitian kuantitatif dengan metode pengumpulan data berupa survei, dan menggunakan Starbucks Stasiun Jakarta Kota sebagai unit observasi. Data primer dikumpulkan dengan metode purposive sampling, dan terkumpul sebanyak 100 responden yang berkaitan langsung dengan kampanye Cup Of Courage. Analisis data menggunakan SPSS di windows 15. Berdasarkan hasil penelitian yang dilakukan terdapat pengaruh yang sangat kuat antara kampanye Cup Of Courage terhadap minat beli produk minuman Pink Voice, yang berada di interval 0,8-1,00 pada hasil uji Koefisien Korelasi.
\end{abstract}

Kata Kunci: aida, kampanye, minat beli

\section{Pendahuluan}

Hasil riset yang dikeluarkan oleh TOFFIN, penyedia dibidang solusi bisnis berupa barang dan jasa di industri hotel, restoran, dan kafe, bersama Majalah MIX MarComm edisi 2019 mencatat jumlah kedai kopi di Indonesia mencapai lebih dari 2.950 gerai (terhitung pada Agustus 2019). Hal tersebut terjadi seiring dengan meningkatnya konsumsi kopi di Indonesia. Salah satu perusahaan terbesar di dunia 
dalam bidang industri kopi ialah Starbucks. Starbucks merupakan sebuah perusahaan asing yang bergerak dalam industri kopi yang pertama kali didirikan pada tahun 1971 dengan kantor pusat yang berlokasi di Seattle, WA, United States (Tu, Wang, dan Chang, 2012).

Dikutip melalui Media Kumparan.com, Starbucks mulai mengembangkan bisnisnya di Indonesia pada 2001 melalui perusahaan mitra di Indonesia PT Mitra Adi Perkasa Tbk, dengan gerai kedai kopi pertama yang berlokasi di pusat perbelanjaan Plaza Indonesia. Menurut data terakhir yang tercatat pada bulan Januari 2018, jumlah gerai Starbucks sudah mencapai 344 gerai yang tersebar di seluruh Indonesia. Dalam 18 tahun kehadirannya di industri kopi Indonesia, Starbucks sudah melakukan berbagai program public relations berupa kampanye sosial, untuk membuat lingkungan hidup yang lebih baik.

Salah satu kampanye yang dilakukan Starbucks adalah Pink Voice. Dalam memperingati Bulan Kesadaran Kanker Payudara Nasional yang jatuh pada bulan Oktober 2017, Starbucks Indonesia melakukan kerjasama dengan organisasi nonprofit yang bergerak dibidang kegiatan sosialisasi deteksi dini kanker payudara (Lovepink Indonesia atau Yayasan Daya Dara) untuk meluncurkan \#PINKVOICE, sebuah kampanye yang bertujuan untuk meningkatkan kesadaran masyarakat mengenai kanker payudara. Sepanjang Oktober 2017, seluruh gerai Starbucks yang berada di Indonesia menawarkan minuman berwarna merah muda (pink) khusus dan menyumbangkan $10 \%$ dari seluruh total penjualannya untuk LovePink Indonesia. Pada tahun 2019, Starbucks kembali membuat kampanye \#LOVEPINK dengan membawa tema "Cup Of Courage". Dengan penggunaan tema baru ini Starbucks ingin memberikan semangat yang menginspirasi terhadap sesama, sesuai dengan nilai yang diyakini Starbucks, yaitu memupuk semangat kemanusiaan.

Pada penelitian ini peneliti ingin mengetahui pengaruh yang diberikan kampanye Cup Of Courage terhadap minat beli produk minuman Pink Voice di Starbucks Stasiun Jakarta Kota. Menurut Ridout dan Franz (2011) dalam Venus (2019), pesan yang ingin disampaikan dalam sebuah kampanye, harus memiliki aspek Stimulating (memiliki daya rangsang), Appealing (memiliki kemampuan menarik perhatian), dan Reasoning (memberikan alasan untuk bertindak).

Menurut Mowen (1995) dalam Meldarianda \& Lisan (2010) menyatakan definisi minat beli adalah kecenderungan konsumen untuk melakukan pembelian terhadap suatu merek yang berkaitan dengan pembelian yang diukur melalui tingkat kemungkinan seseorang melakukan pembelian. Definisi minat beli juga dikemukakan oleh Blackwell \& Engel (2008) dalam (Ningrum, 2016), dikemukakan bahwa, minat beli merupakan keinginan dalam diri suatu individu untuk mengarahkan perhatian tanpa adanya paksaan pada suatu produk yang berakhir dengan dilakukannya tindakan pembelian.

Menurut Suwandari (2008) dalam Rizky, Yasin (2014) terdapat empat indikator yang disebut sebagai konsep AIDA. Menurut konsep ini, terdapat empat indikator yang menjadi pedoman bagi seorang calon konsumen untuk tertarik melakukan pembelian, yaitu Perhatian (attention) yaitu perhatian calon konsumen terhadap sebuah produk yang ditawarkan oleh sebuah produk, Ketertarikan (interest), ketertarikan seseorang terhadap barang atau jasa yang ditawarkan oleh produsen, Keinginan (desire), perilaku calon konsumen untuk ingin memiliki produk yang ditawarkan oleh produsen, Tindakan (action), calon konsumen yang menghasilkan sebuah aksi/tindakan, yaitu melakukan tindakan pembelian terhadap produk yang ditawarkan. Pada penelitian ini, peneliti ingin mengetahui bagaimana tiga aspek yang 
dimiliki kampanye, apakah memiliki pengaruh yang signifikan terhadap indikator yang dimiliki.

\section{Gambar 1. Kerangka Pemikiran}

\begin{tabular}{|c|c|}
\hline Kampanye Cup Of Courage & Minat Beli \\
(X) & $(\mathbf{Y})$ \\
Stimulating \\
Appealing \\
Reasoning
\end{tabular}$\quad \begin{gathered}\text { Perhatian } \\
\text { (attention) } \\
\text { Ketertarikan } \\
\text { (intorost) }\end{gathered}$

Sumber: Dokumentasi Hasil Penelitian

Hipotesis : Adanya pengaruh antara kampanye Cup Of Courage terhadap minat beli produk minuman Pink Voice di Starbucks Stasiun JakartaKota

\section{Metode Penelitian}

Peneliti menggunakan metode kuantitatif dalam penelitian ini dengan metode pengumpulan data menggunakan kuesioner. Kuesioner adalah sebuah alat yang digunakan sebagai pengumpul data primer dengan metode survei untuk memperoleh berbagai data dari responden (Atmaja dan Wijaya, 2019). Pada kuesioner ini, skala pengukuran yang akan digunakan adalah Skala Likert. Skala Likert adalah skala ordinal 5 poin yang digunakan oleh responden untuk memberikan sebuah jawaban atas sejauh mana mereka setuju atau tidak setuju terhadap sebuah pernyataan atau pertanyaan yang diajukan peneliti (Gail, Sullivan, dan Artino, 2013).

Peneliti melakukan triangulasi data untuk menggali data yang dibutuhkan peneliti dan untuk melengkapi serta memperkuat data. Metode yang digunakan adalah wawancara. Menurut Stewart \& Cash wawancara merupakan sebuah interaksi yang di dalamnya terdapat pertukaran, tanggung jawab, perasaan, kepercayaan, motif, dan informasi (Herdiansyah, 2010). Peneliti melakukan wawancara dengan Store Manager Starbucks Stasiun JakartaKota yang menjabat pada Oktober 2019 hingga saat ini.

Dalam penelitian kuesioner yang digunakan berjumlah 100 kuesioner. Kuesioner disebarkan kepada para responden yang merupakan konsumen yang pernah membeli produk minuman Pink Voice dari kampanye Cup Of Courage pada bulan Oktober 2019 lalu. Peneliti akan melakukan penyebaran kuesioner melalui google form kepada para konsumen kepada para konsumen yang memenuhi kriteria responden. Data responden diperoleh dari Starbucks Stasiun JakartaKota. Data akan digunakan peneliti untuk menghubungi langsung para responden melalui berbagai digital platform yang ada. Dalam penelitian ini peneliti menggunakan teknik pengumpulan data yang dinamakan Purposive Sampling. Menurut Santoso dan Tjiptono (2008) dalam (Hendarsono dan Sugiharto, 2013) Purposive Sampling adalah metode yang digunakan untuk memilih sampel yang memiliki kriteria khusus. Pengolahan data dilakukan dengan menggunakan (SPSS) versi 15. Teknik analisis data yang dilakukan adalah, Uji Koefisien Korelasi, Uji Analisis Regresi Sederhana, Uji Signifikan Pengaruh Parsial (Uji T), dan Uji Koefisien Determinasi ( $\left.\mathrm{R}^{2}\right)$. 


\section{Hasil Temuan dan Diskusi}

Dalam penelitian yang dilakukan ini, peneliti berhasil menyebarkan 100 kuesioner kepada responden yang memenuhi kriteria. Dari hasil pengumpulan data dapat dikethaui $45 \%$ responden berjenis kelamin laki-laki, dan 55\% responden berjenis kelamin perempuan. Dalam penelitian ini juga didapat data usia responden 18-22 tahun sebanyak 23\%, 23-27 tahun sebanyak 36\%, 28-32 tahun sebanyak 30\%, dan diatas 32 tahun sebanyak $11 \%$.

Setelah melakukan berbagai analasis data dan uji keabsahan data dengan memanfaatkan aplikasi SPSS ver 15, maka didapatkan hasil sebagai berikut.

Tabel 1. Uji Validitas

\begin{tabular}{|c|c|c|c|c|}
\hline Variabel & $\begin{array}{l}\text { Butir } \\
\text { indikator }\end{array}$ & $\begin{array}{l}\text { Corrected } \\
\text { Item-Total } \\
\text { Correlation }\end{array}$ & $\begin{array}{l}\text { Batas } \\
\text { Angka } \\
\text { Korelasi }\end{array}$ & Kesimpulan \\
\hline \multirow{9}{*}{$\begin{array}{l}\text { Kampanye } \\
\text { Cup Of } \\
\text { Courage } \\
\text { (X) }\end{array}$} & $\mathrm{X} 1$ & .447 & .200 & VALID \\
\hline & $\mathrm{X} 2$ & .542 & .200 & VALID \\
\hline & $\mathrm{X} 3$ & .66 & .200 & VALID \\
\hline & $\mathrm{X} 4$ & .70 & .200 & VALID \\
\hline & $\mathrm{X} 5$ & .71 & .200 & VALID \\
\hline & X6 & .38 & .200 & VALID \\
\hline & $\mathrm{X} 7$ & .55 & .200 & VALID \\
\hline & $\mathrm{X} 8$ & .53 & .200 & VALID \\
\hline & X9 & .49 & .200 & VALID \\
\hline \multirow{11}{*}{$\begin{array}{l}\text { Minat Beli } \\
\text { (Y) }\end{array}$} & $\mathrm{Y} 1$ & .55 & .200 & VALID \\
\hline & Y2 & .55 & .200 & VALID \\
\hline & Y3 & .57 & .200 & VALID \\
\hline & Y4 & .59 & .200 & VALID \\
\hline & Y5 & .60 & .200 & VALID \\
\hline & Y6 & .61 & .200 & VALID \\
\hline & Y7 & .56 & .200 & VALID \\
\hline & Y8 & .62 & .200 & VALID \\
\hline & Y9 & .57 & .200 & VALID \\
\hline & Y10 & .66 & .200 & VALID \\
\hline & Y11 & .46 & .200 & VALID \\
\hline
\end{tabular}

Sumber: Hasil yang diolah dengan SPSS 15

Menurut Morrisan dalam (Aprianto, dan Candraningrum, 2020) Pengukuran pada populasi harus menggunakan alat ukur yang valid. Menurut Nisfiannoor (2013:298), untuk menilai apakah butir dalam kuesioner valid atau tidak, adalah dengan cara melihat apakah nilai Corrected Item - Total Correlation atau angka korelasi di atas 0,2. Bila angka korelasi bernilai diatas 0,2 maka setiap item pertanyaan dinyatakan valid. Pada tabel 1 menunjukkan bahwa seluruh butir indikator yang terdapat dalam penelitian ini valid seluruhnya, karena memiliki angka Corrected Item- 
Total Correlation diatas 0,2 yang memiliki arti bahwa setiap indikator dalam penelitian ini adalah valid. Pada penelitian ini peneliti juga melakukan uji reliabilitas untuk melihat apakah variabel yang digunakan dalam penelitian ini reliabel atau tidak. Menurut Siregar (2013) reliabilitas dianggap reliabel apabila nilai Cronbach's Alpha terhitung lebih besar dari 0,6. Pada penelitian ini didapatkan hasil bahwa variabel Kampanye (X) memiliki nilai 0,833 dan variabel Minat Beli (Y) memiliki nilai 0,871 . Hal ini menandakan bahwa kedua variabel dianggap reliabel (Cronbach's Alpha $<0,6$ ).

Hasil uji normalitas dalam penelitian mendapatkan hasil bahwa data terdistribusi secara normal. Menurut Gujarati dalam (Putri, Setiawina, 2013), bila angka sig $>$ Alpha menandakan data terdistribusi dengan normal, dan bila sig $<$ Alpha menandakan data terdistribusi secara tidak normal. (Alpha $=0,05)$. Hasil uji normalitas yang dilakukan peneliti menunjukkan bahwa nilai Asymp. Sig (2-tailed) pada variabel dependen Minat Beli (Y) sebesar 0,248 dan pada variabel independen Kampanye (Y) sebesar 0,174. Dari kedua hasil uji normalitas yang muncul dapat diartikan bahwa penyebaran data pada penelitian ini terdistribusi secara normal.

Tabel 2. Hasil Uji Pengaruh Parsial (Uji T)

\begin{tabular}{|l|r|r|c|c|r|}
\hline & \multicolumn{2}{|c|}{$\begin{array}{c}\text { Unstandardized } \\
\text { Coefficients }\end{array}$} & $\begin{array}{c}\text { Standardized } \\
\text { Coefficients }\end{array}$ & $\mathrm{t}$ & \multicolumn{1}{c|}{ Sig. } \\
\cline { 2 - 6 } & \multicolumn{1}{|c|}{$\mathrm{B}$} & Std. Error & Beta & \multicolumn{1}{c|}{$\mathrm{B}$} & Std. Error \\
\hline (Constant) & 3.894 & 1.232 & & 3.161 & .002 \\
T.X & .959 & .069 & .816 & 13.950 & .000 \\
\hline
\end{tabular}

Sumber: Hasil yang diolah dengan SPSS

Menurut Siregar (2015) jika nilai sig $<0,05$ maka variabel bebas memiliki pengaruh secara signifikan terhadap variabel terikat. Pada tabel 2 menunjukkan bahwa variabel bebas berpengaruh secara signifikan terhadap variabel terikat dikarenakan didapatkan nilai sig sebesar $0,000(<0,05)$. Dengan adanya hasil ini menunjukkan bahwa $\mathrm{H}_{1}$ diterima bahwa variabel kampanye $(\mathrm{X})$ memiliki pengaruh yang signifikan terhadap variabel minat beli (Y). Pada tabel 2 juga dapat dilihat hasil persamaan regresi linear yang muncul, dengan pengertian Nilai 3.894 menandakan bahwa nilai Minat beli produk minuman Pink Voice (Y) akan tetap konstan sebesar 3.894 jika nilai Kampanye Cup Of Courage (X) tidak mengalami perubahan naik ataupun turun. Nilai 0.959 merupakan koefisien regresi yang menunjukkan bahwa setiap ada penambahan suatu nilai atau angka untuk Kampanye Cup Of Courage, maka akan ada kenaikan Minat beli produk minuman Pink Voice senilai 0.959.dengan begitu semakin bertambahnya nilai $\mathrm{X}$ akan memherdiansyah engaruhi nilai $\mathrm{Y}$.

Tabel 3. Hasil Koefisien Korelasi

\begin{tabular}{|l|c|r|r|r|}
\hline Model & $\mathrm{R}$ & R Square & $\begin{array}{c}\text { Adjusted R } \\
\text { Square }\end{array}$ & Std. Error of the Estimate \\
\hline 1 & $.816(\mathrm{a})$ & .665 & .662 & 3.08069 \\
\hline
\end{tabular}

Sumber: Hasil yang diolah dengan SPSS

Pada tabel 3 menunjukkan bahwa terdapat hubungan yang sangat erat antara variabel $\mathrm{X}$ dan $\mathrm{Y}$. Dapat dikatakan sangat erat atau sangat tinggi karena nilai $\mathrm{R}(0,816)$ berada dalam interval 0,8-1,00. Dengan adanya hasil uji koefisien korelasi ini mengartikan bahwa terdapat hubungan yang sangat kuat antara variabel kampanye (X) 
dengan variabel minat beli (Y). Pada tabel 3 juga menunjukkan bahwa kemampuan variabel kampanye Cup Of Courage (X) dalam memberikan kontribusi terhadap variabel Minat beli produk minuman Pink Voice (Y). Hal ini dapat dilihat melalui nilai koefisien determinasi $\left(\mathrm{R}^{2}\right)$ yang memiliki nilai sebesar $66,5 \%$, sementara sisa $33,5 \%$ dijelaskan oleh berbagai faktor yang tidak diteliti dalam penelitian ini.

\section{Kesimpulan}

Berdasarkan hasil pembahasan dan hasil penelitian yang telah peneliti lakukan mengenai pengaruh kampanye Cup Of Courage terhadap minat beli konsumen di Starbucks Stasiun JakartaKota, maka penulis menarik kesimpulan bahwa variabel kampanye Cup Of Courage memiliki pengaruh yang sangat kuat terhadap variabel minat beli konsumen di Starbucks Stasiun JakartaKota. Variabel kampanye memiliki tiga dimensi yaitu, Stimulating, Appealing, Reasoning. Dari ketiga dimensi tersebut indikator yang memiliki pengaruh paling tinggi terdapat di dimensi Action. Dengan adanya dimensi didalam kampanye yang dapat merubah tindakan konsumen, dapat memberikan dampak positif kepada minat beli konsumen.

Kampanye Cup Of Courage dapat dikatakan memiliki pengaruh yang sangat kuat terhadap minat beli konsumen dikarenakan hasil Uji Koefisien Korelasi yang menunjukkan angka 0,816. Melalui hasil Uji Signifikansi Parsial pada tabel 4.27, peneliti juga dapat menarik kesimpulan bahwa variabel Kampanye (X) memiliki pengaruh yang signifikan terhadap variabel minat beli (Y) dengan nilai sig sebesar 0,000 atau $<0,05$.

\section{Ucapan Terima Kasih}

Peneliti ingin mengucapkan terima kasih kepada para responden yang telah bersedia terlibat dalam memberikan data pada penelitian ini guna pelaksanaan penelitian. Ucapan terima kasih juga peneliti ucapkan pada Fakultas Ilmu Komunikasi Universitas Tarumanagara, keluarga, teman, dan semua pihak yang membantu proses penyusunan penelitian ini sampai selesai.

\section{Daftar Pustaka}

Aprianto, Nico. Candraningrum,DA. (2020). Pengaruh Personal Selling terhadap Minat Beli Produk PRUlink Generasi Baru Nasabah Prudential Life Assurance Indonesia. Jurnal Komunikasi Untar Prologia. Vol. 3, No. 2, Desember 2019, Hal 313-319.

Atmaja, K. J., \& Wijaya, I. N. S. W. (2019). Pengembangan Sistem Evaluasi Kinerja Dosen (E-Kuesioner) Stmik Stikom Indonesia.JST (Jurnal Sains dan Teknologi), Vol. 8, No. 1, Hal 55-64.

Hendarsono, Gersom. Sugiharto, Sugiono. (2013). Analisa Pengaruh Experiential Marketing Terhadap Minat Beli Ulang Konsumen Cafe Buntos 99 Sidoarjo. Jurnal Manajemen Pemasaran, Vol. 1, No. 2, Hal 1-8.

Herdiansyah, Haris. (2010). Metedologi Penelitian Kualitatis Untuk Ilmu-Ilmu Sosial. Jakarta Selatan: Salemba Humanika.

Meldarianda, Resti. Henky, Lisan S. (2010). Pengaruh Store Atmosphere Terhadap Minat beli produk minuman Pink Voice Pada Resort Café Atmosphere Bandung. Jurnal Bisnis dan Ekonomi (JBE), September 2010, Hal. 97 - 108. 
Ningrum, I. T. J., \& Nilowardono, S. (2016). Pengaruh Event dan Brand Image Terhadap Minat Beli Produk Rokok Sampoerna A Mild Pada PT HM Sampoerna Area Marketing Surabaya. Jurnal Manajemen Kinerja. Vol. 2, No. 1, Hal. 5769.

Nisfiannoor, Muhammad. (2013). Pendekatan Statistika Modern Aplikasi dengan Software SPSS dan E-Views. Jakarta: Penerbit Universitas Trisakti.

Putri, A. D., \& Setiawina, D. (2013). Pengaruh Umur, Pendidikan, Pekerjaan Terhadap Pendapatan Rumah Tangga Miskin Di Desa Bebandem. Jurnal Ekonomi Pembangunan Universitas Udayana, Vol. 2 No.4. Hal. 173-180. ISSN 23030178

Rizky, Muhammad Fakhru.Nst. Yasin, Hanifa. (2014). Pengaruh Promosi Dan Harga Terhadap Minat Beli Perumahan Obama Pt. Nailah Adi Kurnia Sei Mencirim Medan. Jurnal Manajemen \& Bisnis. Vol. 14 No. 02 Oktober 2014 ISSN 16937619.

Siregar, S. (2013). Metode Penelitian Kuantitatif. Jakarta: PT Fajar Interpratama Mandiri

Siregar, Syofian. (2015). Statistika Terapan Untuk Perguruan Tinggi. Jakarta: PT Kharisma Putra Utama

Sullivan, G. M., \& Artino Jr, A. R. (2013). Analyzing and interpreting data from Likert-type scales. Journal of graduate medical education, Vol. 5, No. 4, 541542. December 2013

Venus, Antar. (2019). Manajemen Kampanye: Panduan Teoretis dan Praktis dalam Mengefektifkan Kampanye Komunikasi. Edisi Revisi. Bandung: Simbiosa Rekatama Media.

Yu-Te Tu,Chin-Mei Wang,Hsiao-ChienChang. (2012). Corporate Brand Image and Customer Satisfaction on Loyalty: An Empirical Study of StarbucksCoffee in Taiwan. Journal Of Social and Development Science. Vol. 3, No. 1, pp. 24-23. Februari 19. 2020. 